\title{
ADVERSE DRUG REACTIONS AND ATRIOVENTRICULAR CONDUCTION DISORDERS - A FEMALE GENDER RELATED APROACH
}

\author{
Dragoș Traian Marius Marcu, Cătălina Arsenescu-Georgescu \\ University of Medicine and Pharmacy "Grigore T. Popa" Iași \\ Corresponding author: Dragoș Traian Marius Marcu \\ Department of Internal Medicine, University of Medicine and Pharmacy "Grigore T. Popa" \\ Iași, Strada Universității, No. 16, Iași 700115, Romania; \\ e-mail: dragos.marcu11@yahoo.com
}

\section{Rezumat}

Introducere. Deși bolile cardiovasculare rămân principala cauză de mortalitate indiferent de gen, genul feminin a rămas o populație subreprezentată în studiile în domeniu. Inițiative susținute ale Societății Europene de Cardiologie au adus în prim plan importanța studierii diferențelor de gen în privința profilului de siguranță al medicamentelor cardiovasculare în cazul femeilor. Printre efectele adverse medicamentoase frecvente, cardiovasculare, se numără tulburările de conducere atrio-ventriculară.

Material și metodă. Studiul prezentat a urmărit particularitățile clinico-paraclinice ale pacienților de gen feminin cu un diagnostic principal, la internare, de bradicardie, în relație cu medicația bradicardizantă. Am inclus un lot de 359 pacienți de gen feminin, împărțit în funcție de prezența sau absența medicației bradicardizante într-un lot studiu $(n=206)$ și un lot martor $(n=153)$.

Rezultate. Pacienții care au asociat medicație bradicardizantă au necesitat frecvent internare în urgență $(P<0,001)$, cu o durată prelungită a spitalizării $(P<0,001)$. Principalele tulburări de conducere atrio-ventriculară identificate au fost fibriația atrială cu alură ventriculară lentă $(P$ $=0,028)$, bradicardia sinusală $(P=0,009)$ și pauzele sinusale $(P=0,009)$. Dintre comorbidități, insuficiența cardiacă $(P<0,001)$ și boala renală cronică $(P<0,001)$, au fost frecvente în lotul de studiu. Parametrii ecocardiografici de dilatare ventriculară stângă $(P=0,002)$ și biatrială $(P$ $<0,001)$, precum și disfuncția sistolică severă a ventriculului stâng $(P=0,009)$, au prezentat semnificație statistică în acest lot. Cele mai frecvent utilizate medicamente au fost betablocantele, amiodarona și digoxinul.

Concluzii. Rezultatele noastre indică, ca factori asociați bradiaritmiilor legate de medicație, la genul feminin: insuficiența cardiacă cu disfuncție sistolică severă, disfuncția renală, fibrilația atrială și dilatarea ventriculară stângă.

Cuvinte cheie: tulburări de conducere atrio-ventriculară, gen feminin, medicație bradicardizantă. 


\title{
INTERNAL MEDICINE
} Original Papers

\begin{abstract}
Introduction. Although cardiovascular disease remains the leading cause of mortality regardless of gender, the female gender has remained an underrepresented population in studies in this field. Sustained initiatives by the European Society of Cardiology have brought to the fore the importance of studying gender differences regarding the safety profile of cardiovascular drugs in women. Common cardiovascular adverse drug reactions include atrioventricular conduction disorders.
\end{abstract}

Materials and methods. The present study followed the clinical and paraclinical features of female patients with a primary diagnosis of bradycardia in relation to bradycardic medication. We included a group of 359 female patients, divided according to the presence or absence of bradycardia medication into a study group $(n=206)$ and a control group $(n=153)$.

Results. Patients with associated bradycardic medication frequently required emergency admission $(P<0.001)$, with prolonged hospitalization $(P<0.001)$. The main atrioventricular conduction disorders identified were atrial fibrillation with slow ventricular response $(P=$ $0.028)$, sinus bradycardia $(P=0.009)$ and sinus pauses $(P=0.009)$. Among comorbidities, heart failure $(P<0.001)$ and chronic kidney disease $(P<0.001)$, were common in the study group. Echocardiographic parameters of left ventricular $(P=0.002)$ and biatrial $(P<0.001)$ dilatation, as well as severe left ventricular systolic dysfunction $(P=0.009)$, showed statistical significance in this group. The most used drugs were beta-blockers, amiodarone, and digoxin.

Conclusions. Our results indicate, as factors associated with medication-related bradyarrhythmias in female gender: heart failure with severe systolic dysfunction, renal dysfunction, atrial fibrillation, and left ventricular dilatation.

Keywords: atrioventricular conduction disorders, female gender, bradycardic medication. 


\section{Introduction}

Cardiovascular diseases (CVD) are the leading cause of morbidity and mortality in both men and women ${ }^{(1)}$. Cardiovascular risk in women has been underestimated and little studied until today. The protective role of hormones disappears with the onset of menopause, leading to an increase in CVD incidence. After the age of 65, CVD are the leading cause of death in women. The lack of evidence on the gender difference in the efficacy and safety of cardiovascular therapeutic interventions are a consequence of is a consequence of the predominant inclusion of male patients in large clinical trials ${ }^{(2)}$.

The influence of gender on the effects of medication in various cardiovascular pathologies is not fully known. Differences in anatomical structure and function are reflected in pharmacokinetics and pharmacodynamics characteristics. Body composition, drug absorption, plasma, and tissue distribution, metabolizing enzymes and transporters or drug excretion influence the pharmacokinetics of various drugs. Women have a lower gastric acid secretion and gastrointestinal transit time which leads to a decrease in the absorption of some betablockers (BB) such as metoprolol or verapamil (they need an acidic environment for absorption) ${ }^{(3)}$. Female specific hormones interfere in the metabolic process as plasma protein binding agents, but their effect needs further research in this field. In addition to the physiological aspects mentioned above, anatomical conformation plays a special role in drug metabolism in women as they have a higher percent of body fat and lower organ size, blood flow and plasma volume. Drugs which require loading-dosages such as amiodarone or digoxin reach higher serum level concentration than in men, leading to more adverse drug reactions (ADRs). Both renal and hepatic clearance depend on the cardiac output and are lower in women which leads to differences in drug-metabolizing enzymes and transporters as well as a more slowly clearance of drugs primarily excreted unchanged in the urine $e^{(2,4)}$.

\section{Objectives}

The present study aimed to capture the clinical and paraclinical features of female patients with a main diagnosis on admission, of symptomatic bradycardia in relation to bradycardic medication.

\section{Material and methods}

We included a cohort of 359 female patients admitted to a single tertiary referral center in the North-East Romania for a symptomatic atrioventricular conduction disorder. We divided this group according to the presence or absence of bradycardic medication into a study group $(n=206)$ and a control group $(n=153)$, respectively. Age under 18 years, the diagnosis of an acute coronary syndrome, previous pacemaker implantation as well as post-interventional or post-surgical atrioventricular conduction disorders were exclusion criteria.

The statistical analysis covered a variety of parameters such as demographic characteristics, comorbidities, vital signs at presentation, laboratory results and use of $\beta$ blockers among the two groups (patients with $\beta$-blockers and controls). Descriptive statistics (frequency, percentage, mean, standard deviation) as well as inferential statistics were used. Numerical data was recorded as mean \pm standard deviation (SD). Categorical data was presented as absolute 


\section{Original Papers}

values and percentages. A Chi square test ( $\chi 2$ test) or Fisher Exact test was used to assess differences between categorical variables. Independent t-test (parametric analysis) and Mann-Whitney $U$ test (non-parametric analysis) was used to test the differences between numerical variables. The chosen significance threshold for $P$ value was 0.05 . All statistical calculations were performed using the SPSS statistics software (version 20, IBM).

\section{Results}

We included in our study 359 female patients, 206 in the study group (based on the use of medication) and 153 in the control group (without any bradycardic medication). The demographic characteristics and comorbidities associated are presented in Table 1 . The mean age was slightly higher in the study group $(73.66 \pm 9.28$ yrs vs. $74.18 \pm$ 8.76 yrs, $P=0,591$ ) as well as the mean value of body mass index $\left(27.99 \pm 5.66 \mathrm{~kg} / \mathrm{m}^{2}\right.$ vs. $28.07 \pm 6.78 \mathrm{~kg} / \mathrm{m}^{2}, \mathrm{P}=0.628$ ).

Both hypertension and diabetes mellitus were moreover present in the cases group (76.7\% vs. $76.5 \%, \mathrm{P}=0.181$, respectively $26.2 \%$ vs. $18.3 \%, P=0.077$ ). More patients in the first group associated acute kidney injury (18.0\% vs. 9.8\%, $\mathrm{P}=0.030$ ), chronic kidney disease $(28.6 \%$ vs. $13.1 \%, \mathrm{P}<0.001)$ or chronic kidney disease without exacerbation
( $20.9 \%$ vs. $7.2 \%, P<0.001$ ), indicating a solid association between the use of antiarrhythmic medication and renal pathology. Statistical analysis revealed a statistically significant value for the association of heart failure in our study ( $31.6 \%$ vs. $14.4 \%, \mathrm{P}<0.001$ ).

Table 2 shows the vital signs at admission and the electrocardiographic findings. Emergency hospitalization (58.3\% vs. 37.9\%, $\mathrm{P}<0.001)$ and temporary cardiac pacing (14.6\% vs. $13.1 \%, P=0.687$ ) were more frequent in the cases group.

The mean values and SD of systolic blood pressure (142.85 $\pm 28.83 \mathrm{mmHg}$ vs. $151.58 \pm$ 28.81, $\mathrm{P}=0.005)$ and diastolic blood pressure $(74.39 \pm 13.83 \mathrm{mmHg}$ vs. $75.78 \pm 13.86$ $\mathrm{mmHg}, \mathrm{P}=0.348$ ) were increased in the female group without antiarrhythmic medication, compared to the higher mean values of the heart rate in patients with antiarrhythmic medication (58.56 \pm 24.62 bpm vs. $51.54 \pm 22.00$ bpm, $\mathrm{P}=0.003$ ). Slow ventricular response atrial fibrillation was more frequent in the cases group $(21.4 \%$ vs. $12.4 \%, P=0.028$ ), while sinus bradycardia and sinus pauses were identified only in the first group, having a statistically significant value $(P=0.009)$. The absence of bundle branch block morphology prior to conduction disorder was statistically significant ( $P$ $=0.009$ ) and more frequent in the control group (74.3\% vs. $85.6 \%$ ). 


\begin{tabular}{|c|c|c|c|}
\hline Parameters & $\begin{array}{l}\text { Study group } \\
\text { (with } \\
\text { medication) } \\
n=206\end{array}$ & $\begin{array}{l}\text { Control group } \\
\text { (without } \\
\text { medication) } \\
n=153\end{array}$ & P value \\
\hline Age, yrs & $73.66 \pm 9.28$ & $74.18 \pm 8.76$ & 0.591 \\
\hline $\begin{array}{l}\text { Originating area (urban vs. } \\
\text { rural) }\end{array}$ & $115(55.8 \%)$ & $71(46.4 \%)$ & 0.077 \\
\hline Body mass index, $\mathrm{kg} / \mathrm{m}^{2}$ & $27.99 \pm 5.66$ & $28.07 \pm 6.78$ & 0.628 \\
\hline $\begin{array}{l}\text { Duration of hospitalization, } \\
\text { days }\end{array}$ & $6.65 \pm 3.59$ & $4.89 \pm 2.42$ & $<0.001$ \\
\hline Hypertension & $158(76.7 \%)$ & $117(76.5 \%)$ & 0.181 \\
\hline $\begin{array}{l}\text { Grade } 1 \text { hypertension vs. } \\
\text { normal }\end{array}$ & $8(3.9 \%)$ & $5(3.3 \%)$ & 0.758 \\
\hline $\begin{array}{l}\text { Grade } \mathbf{2} \text { hypertension vs. } \\
\text { normal }\end{array}$ & $38(18.4 \%)$ & $16(10.5 \%)$ & 0.036 \\
\hline $\begin{array}{l}\text { Grade } 3 \text { hypertension vs. } \\
\text { normal }\end{array}$ & $112(54.4 \%)$ & $96(62.7 \%)$ & 0.112 \\
\hline Diabetes mellitus & $54(26.2 \%)$ & $28(18.3 \%)$ & 0.077 \\
\hline Acute kidney injury & $37(18.0 \%)$ & $15(9.8 \%)$ & 0.030 \\
\hline Chronic kidney disease & $59(28.6 \%)$ & $20(13.1 \%)$ & $<0.001$ \\
\hline $\begin{array}{l}\text { Chronic kidney disease } \\
\text { without exacerbation }\end{array}$ & $43(20.9 \%)$ & $11(7.2 \%)$ & $<0.001$ \\
\hline Heart failure & $65(31.6 \%)$ & $22(14.4 \%)$ & $<0.001$ \\
\hline $\begin{array}{l}\text { Heart failure - NYHA class } \\
\text { Il vs. normal }\end{array}$ & $42(20.4 \%)$ & $10(6.5 \%)$ & $<0.001$ \\
\hline $\begin{array}{l}\text { Heart failure - NYHA class } \\
\text { III vs. normal }\end{array}$ & $12(5.8 \%)$ & - & 0.002 \\
\hline
\end{tabular}

Table 1. Statistical analysis of demographic data and comorbidities in the two groups, n (\%) 
In terms of the assessed hematological parameters, the statistical analysis revealed slightly higher mean values in the cases group for white blood cells (9193.74 \pm 5118.14 vs. $8659.74 \pm 3252.30 \mathrm{P}=0.210$ ), red blood cells ( $4.42 \pm 0.61$ vs. $4.40 \pm 0.57, P$ $=0.899)$ and hemoglobin $(13.00 \pm 1.61$ vs. $12.93 \pm 1.58, \mathrm{P}=0.889$ ).

There were lower levels of serum natrium in the case group (137.95 $\pm 4.77 \mathrm{mmol} / \mathrm{L}$ vs. $139.22 \pm 3.39 \mathrm{mmol} / \mathrm{L}, \mathrm{P}=0.013$ ) while the serum potassium levels were higher in the study group $(4.52 \pm 0.88 \mathrm{mmol} / \mathrm{L}$ vs. $4.39 \pm$ $0.59 \mathrm{mmol} / \mathrm{L}, \mathrm{P}=0.592$ ). We found eGFR to be statistically significant in our study ( $P$ $=0.006)$ as well as International Normalized Ratio ( $1.57 \pm 1.19$ vs. $1.20 \pm 0.53, \mathrm{P}<0.001)$. Gamma glutamyl transferase serum level was significantly higher in the study group $(61.49 \pm 81.08 \mathrm{U} / \mathrm{L}$ vs. $51.43 \pm 65.29 \mathrm{U} / \mathrm{L}$, $\mathrm{P}=0.054$ ) (Table 3).

The inflammatory parameters evaluated (erythrocyte sedimentation rate, fibrinogen serum level and $C$ reactive protein) had higher mean values in the study group $(P=0.271, P=0.123, P=0.052)$. Regarding the lipid profile we identified similar mean values among total cholesterol (191.84 \pm 47.98 $\mathrm{mg} / \mathrm{dl}$ vs. $190.16 \pm 46.92 \mathrm{mg} / \mathrm{dl}, \mathrm{P}=0.284)$, low-density lipoprotein cholesterol (120.86 \pm $38.44 \mathrm{mg} / \mathrm{dl}$ vs. $116.50 \pm 37.38 \mathrm{mg} / \mathrm{dl}$, $\mathrm{P}=0.852)$, high-density lipoprotein cholesterol $(50.27 \pm 16.15 \mathrm{mg} / \mathrm{dl}$ vs. $49.65 \pm$
$13.58 \mathrm{mg} / \mathrm{dl}, \mathrm{P}=0.371$ ) and triglycerides $(120.88 \pm 60.54 \mathrm{mg} / \mathrm{dl}$ vs. $120.56 \pm 68.51$ $\mathrm{mg} / \mathrm{dl}, \mathrm{P}=0.962)$, but without statistical significance.

Table 4 illustrates the echocardiographic parameters included in the statistical analysis. The association of left ventricular dilation $(8.7 \%$ vs. $1.3 \%, \mathrm{P}=0.002)$, mitral stenosis ( $8.7 \%$ vs. $2 \%, \mathrm{P}=0.007)$, and biatrial enlargement ( $67 \%$ vs. $48.4 \%, \mathrm{P}<0.001)$ are parameters with statistically significance in our study. None of the valvular regurgitation proven to be statistically significant in our study. The mean value of left ventricular ejection fraction was higher in the control group $(52.48 \pm 11.62 \%$ vs. $54.73 \pm 7.74 \%$, $\mathrm{P}=0.494)$. The antiarrhythmic medication used by patients in the study group included a variety of therapeutic classes such as betablockers (150 cases, 72,8\%), digoxin (54 cases, $26,2 \%$ ), amiodarone (39 cases, 18,9\%) and propafenone ( 15 cases, $7,3 \%$ ) (Table 5).

\section{Discussions}

As early as about two decades ago, the first date about the vulnerability of female population to CVD, apeared. In 2006, CVD accounted for $55 \%$ of all deaths in the female population, with no significant improvement over time ${ }^{(5,6)}$. The low inclusion of female population in studies, as well as the neglect of the demographic aspect related to area 


\begin{tabular}{|c|c|c|c|}
\hline Parameters & $\begin{array}{l}\text { Study group } \\
\text { (with medication) } \\
n=206 \\
\end{array}$ & $\begin{array}{l}\text { Control group } \\
\text { (without medication) } \\
n=153\end{array}$ & $\begin{array}{l}P \\
\text { value }\end{array}$ \\
\hline \multicolumn{4}{|l|}{ Clinical presentation } \\
\hline $\begin{array}{l}\text { Emergency } \\
\text { hospitalization }\end{array}$ & $120(58.3 \%)$ & $58(37.9 \%)$ & $<0.001$ \\
\hline SBP, mmHg & $142.85 \pm 28.83$ & $151.58 \pm 28.81$ & 0.005 \\
\hline DBP, mmHg & $74.39 \pm 13.83$ & $75.78 \pm 13.86$ & 0.348 \\
\hline HR, beat/min & $58.56 \pm 24.62$ & $51.54 \pm 22.00$ & 0.003 \\
\hline $\begin{array}{l}\text { Temporary Cardiac } \\
\text { Pacing }\end{array}$ & $30(14.6 \%)$ & $20(13.1 \%)$ & 0.687 \\
\hline Syncope & $110(53.4 \%)$ & $68(44.1 \%)$ & 0.093 \\
\hline \multicolumn{4}{|l|}{ Electrocardiogram } \\
\hline $\begin{array}{l}\text { Type } 2 \text { Second degree } \\
\text { AV block }\end{array}$ & $22(10.7 \%)$ & $27(17.6 \%)$ & 0.057 \\
\hline Third degree AV block & $79(38.3 \%)$ & $70(45.8 \%)$ & 0.159 \\
\hline $\begin{array}{l}\text { Slow ventricular } \\
\text { response atrial } \\
\text { fibrillation } \\
\end{array}$ & $44(21.4 \%)$ & $19(12.4 \%)$ & 0.028 \\
\hline Sinus bradycardia & $9(4.4 \%)$ & - & 0.009 \\
\hline Sick sinus syndrome & $43(20.9 \%)$ & $30(19.6 \%)$ & 0.768 \\
\hline Sinus pauses & $9(4.4 \%)$ & - & 0.009 \\
\hline \multicolumn{4}{|c|}{ Heart rhythm prior to conduction disorder } \\
\hline Sinus rhythm & $149(72.3 \%)$ & $126(82.4 \%)$ & 0.027 \\
\hline Atrial fibrillation & $57(27.7 \%)$ & $27(17.6 \%)$ & 0.027 \\
\hline Atrial flutter & - & - & - \\
\hline \multicolumn{4}{|c|}{ QRS morphology prior to conduction disorder } \\
\hline LBBB & $21(10.2 \%)$ & $6(3.9 \%)$ & 0.026 \\
\hline RBBB & $32(15.5 \%)$ & $16(10.5 \%)$ & 0.162 \\
\hline $\begin{array}{l}\text { Absence of bundle } \\
\text { branch block }\end{array}$ & $153(74.3 \%)$ & $131(85.6 \%)$ & 0.009 \\
\hline \multicolumn{4}{|c|}{ Hemibundle during to conduction disorder } \\
\hline LAFB & $24(11.7 \%)$ & $26(17.0 \%)$ & 0.148 \\
\hline LPFB & $1(0.5 \%)$ & $1(0.7 \%)$ & 0.832 \\
\hline \multicolumn{4}{|c|}{ QRS morphology during conduction disorder } \\
\hline LBBB & $28(13.6 \%)$ & $14(9.2 \%)$ & 0.195 \\
\hline RBBB & $44(21.4 \%)$ & $26(17.0 \%)$ & 0.302 \\
\hline $\begin{array}{l}\text { Absence of bundle } \\
\text { branch block }\end{array}$ & $134(65.0 \%)$ & 113 (73.9\%) & 0.075 \\
\hline
\end{tabular}

Table 2. Clinical presentation and electrocardiogram findings 


\section{INTERNAL MEDICINE}

Original Papers

\begin{tabular}{|c|c|c|c|c|}
\hline Parameters & $\begin{array}{l}\text { Analytical } \\
\text { measurement }\end{array}$ & $\begin{array}{l}\text { Study group } \\
\text { (with } \\
\text { medication) } \\
n=206 \\
\text { mean } \pm \text { SD, } \\
\text { median }\end{array}$ & $\begin{array}{l}\text { Control group } \\
\text { (without } \\
\text { medication) } \\
n=153 \\
\text { mean } \pm \text { SD, } \\
\text { median }\end{array}$ & P value \\
\hline $\mathrm{Na}$ & $\begin{array}{l}135-148 \\
\mathrm{mmol} / \mathrm{L}\end{array}$ & $137.95 \pm 4.77$ & $139.22 \pm 3.39$ & 0.013 \\
\hline $\mathbf{K}$ & $3.5-5.1 \mathrm{mmol} / \mathrm{L}$ & $4.52 \pm 0.88$ & $4.39 \pm 0.59$ & 0.592 \\
\hline $\mathrm{Ca}$ & $\begin{array}{l}1.16-1.35 \\
\mathrm{mmol} / \mathrm{L}\end{array}$ & $1.18 \pm 0.08$ & $1.20 \pm 0.08$ & 0.013 \\
\hline Serum creatinine & $0.5-0.9 \mathrm{mg} / \mathrm{dl}$ & $1.24 \pm 0.65$ & $1.08 \pm 0.47$ & 0.007 \\
\hline Urea & $10-50 \mathrm{mg} / \mathrm{dl}$ & $61.75 \pm 36.48$ & $56.52 \pm 33.55$ & 0.126 \\
\hline eGFR & & $53.11 \pm 21.05$ & $59.03 \pm 19.19$ & 0.006 \\
\hline Uric acid & $2.4-5.7 \mathrm{mg} / \mathrm{dl}$ & $6.73 \pm 2.13$ & $6.39 \pm 2.66$ & 0.114 \\
\hline Glucose & $75-115$ mg/dl & $127.52 \pm 55.90$ & $117.09 \pm 33.33$ & 0.252 \\
\hline $\begin{array}{l}\text { Aspartate } \\
\text { aminotransferase } \\
\text { (AST) }\end{array}$ & $0-31 \mathrm{U} / \mathrm{L}$ & $50.82 \pm 83.29$ & $52.21 \pm 125.17$ & 0.222 \\
\hline $\begin{array}{l}\text { Alanine } \\
\text { aminotransferase } \\
\text { (ALT) }\end{array}$ & $0-31 \mathrm{U} / \mathrm{L}$ & $43.48 \pm 64.07$ & $48.90 \pm 104.99$ & 0.190 \\
\hline $\begin{array}{l}\text { Gamma glutamyl } \\
\text { transferase (GGT) }\end{array}$ & $7-32 \mathrm{U} / \mathrm{L}$ & $61.49 \pm 81.08$ & $51.43 \pm 65.29$ & 0.054 \\
\hline Cholesterol & $0-200 \mathrm{mg} / \mathrm{dl}$ & $191.84 \pm 47.98$ & $190.16 \pm 46.92$ & 0.284 \\
\hline $\begin{array}{l}\text { Low-density } \\
\text { lipoprotein } \\
\text { cholesterol }\end{array}$ & $0-160 \mathrm{mg} / \mathrm{dl}$ & $120.86 \pm 38.44$ & $116.50 \pm 37.38$ & 0.852 \\
\hline
\end{tabular}




\begin{tabular}{|c|c|c|c|c|}
\hline $\begin{array}{l}\text { High-density } \\
\text { lipoprotein } \\
\text { cholesterol }\end{array}$ & $42-98 \mathrm{mg} / \mathrm{dl}$ & $50.27 \pm 16.15$ & $49.65 \pm 13.58$ & 0.371 \\
\hline Triglyceride & $35-150 \mathrm{mg} / \mathrm{dl}$ & $120.88 \pm 60.54$ & $120.56 \pm 68.51$ & 0.962 \\
\hline $\begin{array}{l}\text { International } \\
\text { Normalized Ratio }\end{array}$ & $0.76-1.24$ & $1.57 \pm 1.19$ & $1.20 \pm 0.53$ & $<0.001$ \\
\hline White blood cells & $\begin{array}{l}4000- \\
10500 / \mathrm{mm}^{3}\end{array}$ & $\begin{array}{l}9193.74 \pm \\
5118.14\end{array}$ & $\begin{array}{l}8659.74 \pm \\
3252.30\end{array}$ & 0.210 \\
\hline Red blood cells & $\begin{array}{l}4.2-5.4 \\
\mathrm{mil} / \mathrm{mm}^{3}\end{array}$ & $4.42 \pm 0.61$ & $4.40 \pm 0.57$ & 0.899 \\
\hline Hemoglobin & $12.5-16 \mathrm{~g} / \mathrm{dl}$ & $13.00 \pm 1.61$ & $12.93 \pm 1.58$ & 0.889 \\
\hline $\begin{array}{l}\text { Packed-cell } \\
\text { volume }\end{array}$ & $37-47 \%$ & $39.27 \pm 4.69$ & $39.21 \pm 4.96$ & 0.833 \\
\hline $\begin{array}{l}\text { Mean corpuscular } \\
\text { volume }\end{array}$ & $78-100 \mathrm{fl}$ & $89.23 \pm 5.21$ & $89.05 \pm 5.85$ & 0.599 \\
\hline $\begin{array}{l}\text { Mean corpuscular } \\
\text { hemoglobin }\end{array}$ & $32-36 \mathrm{~g} / \mathrm{dl}$ & $29.81 \pm 0.95$ & $29.35 \pm 2.21$ & 0.906 \\
\hline $\begin{array}{l}\text { Mean corpuscular } \\
\text { hemoglobin } \\
\text { concentration }\end{array}$ & $27-31 \mathrm{pg}$ & $32.81 \pm 0.95$ & $32.84 \pm 1.08$ & 0.795 \\
\hline Thrombocytes & $\begin{array}{l}150000- \\
450000 / \mathrm{mm}^{3}\end{array}$ & $\begin{array}{l}222512.62 \pm \\
75138.94\end{array}$ & $\begin{array}{l}230809.80 \pm \\
74133.58\end{array}$ & 0.118 \\
\hline $\begin{array}{l}\text { Erythrocyte } \\
\text { sedimentation } \\
\text { rate }\end{array}$ & $2-25 \mathrm{~mm} / \mathrm{h}$ & $36.83 \pm 26.23$ & $33.49 \pm 24.89$ & 0.271 \\
\hline C reactive protein & $0-5 \mathrm{mg} / \mathrm{L}$ & $21.74 \pm 36.18$ & $15.46 \pm 22.15$ & 0.123 \\
\hline Serum fibrinogen & $160-500 \mathrm{mg} / \mathrm{dl}$ & $522.38 \pm 146.23$ & $\begin{array}{l}494.30 \pm \\
133.36\end{array}$ & 0.052 \\
\hline
\end{tabular}

Table 3. Laboratory results 


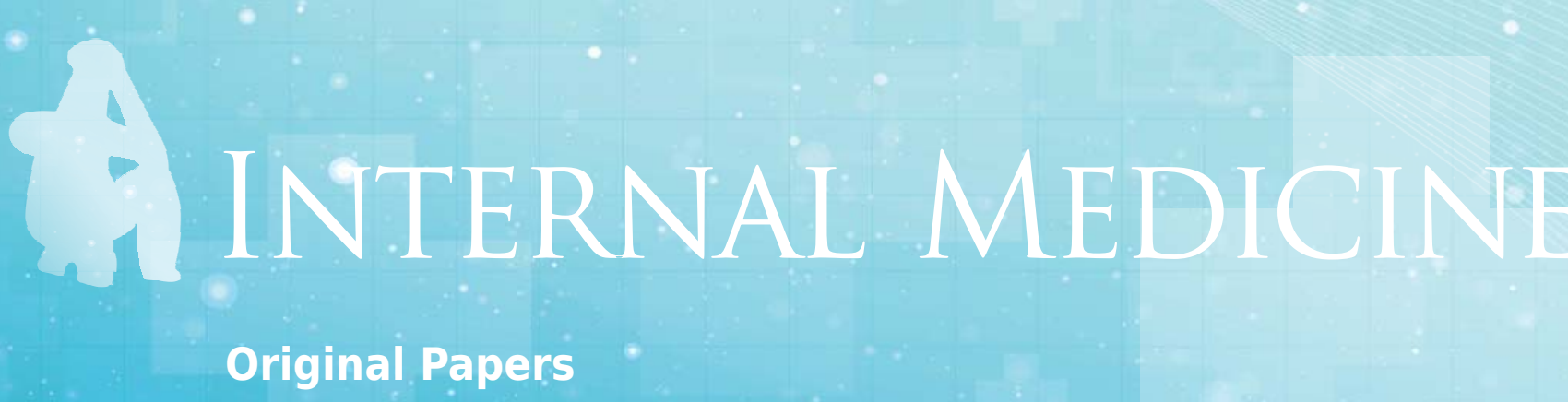

vulnerabilities even at European level, remains a problem that needs to be urgently addressed $^{(7,8)}$.

The present study addresses an unstudied field in the literature, that of atrioventricular conduction disorders related to the presence of medication as well as possible risk factors in female patients. Although the bradycardiadrugs relationship is well known and extensively studied, available studies do not specifically address the female gender issue $(9,10)$.

However, there is evidence in the literature supporting the high vulnerability to adverse drug reactions of certain population groups, including women and the elderly ${ }^{(11-12)}$.

In our study, although the mean age was higher for the study group, it did not show statistical significance, unlike available literature data regarding both genders or only the male gender. It should be noted that the mean age of 73 years is strictly higher than the threshold of 65 years, below which the effects of cardiovascular risk factors are reduced in this population. These findings once again reinforce the idea of the vulnerability of females to ADRs regardless of age ${ }^{(13-15)}$. At the same time, female patients in the study group were more likely to be admitted to the emergency department and to have an extended length of hospital stay, which is also consistent with other data in the literature $^{(16)}$.
Analyzing the main diagnoses at admission, we observed that the study group was statistically associated with atrial fibrillation (AFib) with slow ventricular reponse, sinus bradycardia and sinus pauses, the most frequently identified rhythm on the initial ECG also being AFib. On the other hand, the control group associated a diverse range of atrioventricular conduction disorders, with sinus rhythm on the initial ECG being significantly more prevalent. The statistically significant presence of LBBB prior to the bradycardic episode should also be mentioned, as a sign of degeneration of the excitoconduction system and in the context of more complex comorbidities.

Also, hypertension and diabetes mellitus, risk factors associated with ADRs, did not show statistical significance. However, it should be noted that the systolic blood pressure values were significantly lower in the study group, which can be attributed to the antihypertensive effect of the commonly used beta-blocker medication.

Among the identified comorbidities, heart failure (HF) of any grade showed a significant prevalence in the study group. Analyzing also echocardiographic parameters we observed a significant association dependent on comorbidities - ventricular and biatrial dilatation - frequently associated with HF and AFib or the presence of mitral stenosis - a rare but still present cause of HF. However, further 


\begin{tabular}{|c|c|c|c|}
\hline Parameters & $\begin{array}{l}\text { Study group } \\
\text { (with medication) } \\
n=206\end{array}$ & $\begin{array}{l}\text { Control group } \\
\text { (without medication) } \\
n=153\end{array}$ & $\begin{array}{l}\mathbf{P} \\
\text { value }\end{array}$ \\
\hline Left ventricular dilation & $18(8.7 \%)$ & $2(1.3 \%)$ & 0.002 \\
\hline Aortic stenosis & $39(18.9 \%)$ & $33(21.6 \%)$ & 0.537 \\
\hline Mitral stenosis & $18(8.7 \%)$ & $3(2.0 \%)$ & 0.007 \\
\hline Mitral annular calcification & $117(56.8 \%)$ & $95(62.1 \%)$ & 0.313 \\
\hline Biatrial Enlargement & $138(67.0 \%)$ & $74(48.4 \%)$ & $<0.001$ \\
\hline $\begin{array}{l}\text { Mildly abnormal systolic } \\
\text { dysfunction vs. normal }\end{array}$ & $69(33.5 \%)$ & $67(43.8 \%)$ & 0.047 \\
\hline $\begin{array}{l}\text { Moderately abnormal } \\
\text { systolic dysfunction vs. } \\
\text { normal }\end{array}$ & $17(8.3 \%)$ & $7(4.6 \%)$ & 0.168 \\
\hline $\begin{array}{l}\text { Severly abnormal systolic } \\
\text { vs. normal dysfunction }\end{array}$ & $12(5.8 \%)$ & $1(0.7 \%)$ & 0.009 \\
\hline $\begin{array}{l}\text { Left ventricular septal } \\
\text { hypertrophy }\end{array}$ & $194(94.2 \%)$ & $142(92.8 \%)$ & 0.602 \\
\hline Pulmonary hypertension & $104(50.5 \%)$ & $66(43.1 \%)$ & 0.183 \\
\hline Mitral regurgitation & $159(77.2 \%)$ & $121(79.1 \%)$ & 0.155 \\
\hline Aortic regurgitation & $86(41.7 \%)$ & $74(48.4 \%)$ & 0.143 \\
\hline Tricuspid regurgitation & $148(71.8 \%)$ & $114(74.5 \%)$ & 0.560 \\
\hline Pulmonary regurgitation & $23(11.2 \%)$ & $15(9.8 \%)$ & 0.313 \\
\hline Ejection fraction (\%) & $52.48 \pm 11.62$ & $54.73 \pm 7.74$ & 0.494 \\
\hline $\begin{array}{l}\text { Left ventricular septum } \\
(\mathrm{mm})\end{array}$ & $12.22 \pm 2.11$ & $12.08 \pm 1.95$ & 0.644 \\
\hline
\end{tabular}

Table 4. Ecocardiography findings

Table 5. Medication used in the study group

\begin{tabular}{|l|l|}
\hline Medication & $\mathbf{n}(\%)$ \\
\hline Beta-blockers & $150(72.8 \%)$ \\
\hline Digoxin & $54(26.2 \%)$ \\
\hline Amiodarone & $39(18.9 \%)$ \\
\hline Propafenone & $15(7.3 \%)$ \\
\hline Verapamil & $1(0.5 \%)$ \\
\hline Diltiazem & $2(1.0 \%)$ \\
\hline Ivabradine & $1(0.5 \%)$ \\
\hline Flecainide & $2(1.0 \%)$ \\
\hline
\end{tabular}


analyses are needed to determine the causality relationship, the drugs found in the study group representing guideline indications in the treatment of $\mathrm{HF}$ and $\mathrm{AFib}^{(17-}$ 19). Also, both chronic kidney disease regardless of exacerbation and acute renal dysfunction were significantly associated with the study group. Added to this is the laboratory data, these patients associating high levels of serum creatinine and significantly lower eGFR and serum calcium values, data consistent with other studies in the field(20-21). Among the biochemical parameters analyzed, it is worth mentioning the significantly lower serum sodium values in the study group, possibly in the context of HF-associated hyperhydration and renal dysfunction. At the same time, INR values were significantly higher in this group, which can be explained by the frequent association of AFib with the prevalent use of antivitamin $\mathrm{K}$ at the time of patients' admission.

Regarding the drugs used in the cases group, the vast majority of patients were treated with single therapy or combined therapy with one or more of beta-blockers, amiodarone or digoxin.

Under medication with amiodarone, women have a higher risk to develop Torsade de pointes or other ventricular tachycardias than men due to female predisposition to prolonged cardiac repolarization ${ }^{(22,23)}$. Sex hormones modulate cardiac $\mathrm{K}+$ and $\mathrm{Ca} 2+$ ion channels involved in ventricular repolarization. Estrogens facilitate bradycardia-induced QT prolongation and the emergence of arrhythmias, whereas androgens shortened the QTC and blunted the QT response to drugs ${ }^{(24)}$. ADRs are more frequent in women, the main entities being represented by amiodarone-associated bradycardia which requires permanent pacemaker, dysthyroidism $(29 \%$ in women vs. $17 \%$ in men) and phototoxicity $(21 \%$ in women vs. $8 \%$ in men) as studies have shown ${ }^{(25,26)}$.

Beta-blockers are class II antiarrhythmics used in various cardiovascular diseases. Drug-relates bradyarrhythmias have high prevalence among beta-blocker users. Current studies in this field suggest that older age and female gender are predictors of symptomatic bradyarrhythmias ${ }^{(27,28)}$. The extensive use of beta-blocker medication in these patients is most likely a result of their beneficial effects, suggested by current studies regarding heart failure ${ }^{(29,30)}$.

Between the frequency of ADRs and eGFR there is an inversely proportional relationship. The high prevalence of metoprolol or nebivolol as beta-blockers with hepatic metabolism can be related to the comorbidities associated or the drug-drug interactions. Estrogens and progesterone have a cardiovascular protective role by modulating the cardiac expression of $\beta 1$ - 
adrenoceptors and thus reducing $\beta$ adrenergic-mediated stimulation. Women have increased absorption and may reach higher maximum serum levels as well as slower clearance through CYP2D6 than man which results in a superior reduction in heart rate and blood pressure during physical activity in patients treated with metoprolol or propranolol $^{(24,27)}$.

In our study, digoxin was used by $26.2 \%$ of the female patients enrolled in the study group. Digoxin is widely used in heart failure, its effect being gender related ${ }^{(17)}$. Women develop more frequently ADRs (some studies mention an $50-75 \%$ increase than men) due to polymedication, drug bioavailability and differences in pharmacokinetics and pharmacodynamics. Digoxin is renallyexcreted and requires dosage adjustment due to the slower renal clearance in women (lower serum concentrations of less than 0.8 $\mathrm{ng} / \mathrm{mL}$ are recommended). Serum digoxin levels are influenced by the reduced activity of P-glycoprotein which leads to diminished excretion through the renal tubules ${ }^{(32,33)}$. The mortality rate of all causes in patients treated with digoxin is $5.8 \%$ higher in women. Women treated with digoxin had a smaller reduction in heart failure hospitalization due to recurrent decompensations than men $^{(4,34)}$.

\section{Conclusions}

Our study highlights the need for further research of ADRs in female patients in relation to atrioventricular conduction disorders. Our results show increased risk of medication-related bradyarrhythmias in women, regardless of age, with an increased need for emergency admission and prolonged period of hospitalization. These patients seem more prone towards AFib with slow ventricular response, especially in the case of pre-existing intraventricular conduction disorders (LBBB), and associate multiple important comorbidities such as HF and renal dysfunction. The main drug classes identified were beta-blockers, class III antiarrhythmics (amiodarone) and digoxin. However, our study presents several limitations due to its retrospective nature and further research on this topic is needed.

\section{References}

1. Roth GA, Mensah GA, Johnson CO, et al. Global Burden of Cardiovascular Diseases and Risk Factors, 1990-2019: Update From the GBD 2019 Study. J Am Coll Cardiol. 2020 Dec 22;76(25):2982-3021. doi: 10.1016/j.jacc.2020.11.010. Erratum in: J Am Coll Cardiol. 2021 Apr 20;77(15):1958-1959. PMID: 33309175; PMCID: PMC7755038.

2. Tamargo J, Rosano G, Walther $T$, et al. Gender differences in the effects of cardiovascular drugs. Eur Heart J Cardiovasc Pharmacother. 2017 Jul 1;3(3):163182. doi: 10.1093/ehjcvp/pvw042. PMID: 28329228.

3. Bots SH, Groepenhoff F, Eikendal ALM, Tannenbaum C, Rochon PA, Regitz-Zagrosek V, Miller VM, Day D, Asselbergs FW, den Ruijter HM. Adverse Drug Reactions to Guideline-Recommended Heart Failure Drugs in Women: A Systematic Review of the Literature. JACC Heart Fail. 2019 Mar;7(3):258-266. doi: 10.1016/j. jchf.2019.01.009. PMID: 30819382.

4. Rosano GM, Lewis B, Agewall S, et al. Gender differences in the effect of cardiovascular drugs: a position document of the Working Group on Pharmacology and Drug Therapy of the ESC. Eur HeartJ. 2015 Oct 21;36(40):2677-80. doi: 10.1093/ eurheartj/ehv161. Epub 2015 May 6. PMID: 25948737.

5. Stramba-Badiale M, Fox KM, Priori SG, et al. Cardiovascular diseases in women: a statement from the policy conference of the European Society of Cardiology. Eur Heart J. 2006 Apr;27(8):994-1005. doi: 10.1093/eurheartj/ehi819. Epub 2006 Mar 7. PMID: 16522654.

6. Maas $A H$, van der Schouw YT, Regitz-Zagrosek $V$, et al. Red alert for women's heart: the urgent need for more research and knowledge on cardiovascular disease in women: proceedings of the workshop held in Brussels on gender differences in cardiovascular disease, 29 September 2010. Eur Heart J. 2011 Jun;32(11):1362-8. doi: 10.1093/eurheartj/ehr048. Epub 2011 Mar 15. PMID: 21406440.

7. Townsend $N$, Nichols $M$, Scarborough $P$, Rayner $M$. Cardiovascular disease in Europe--epidemiological 


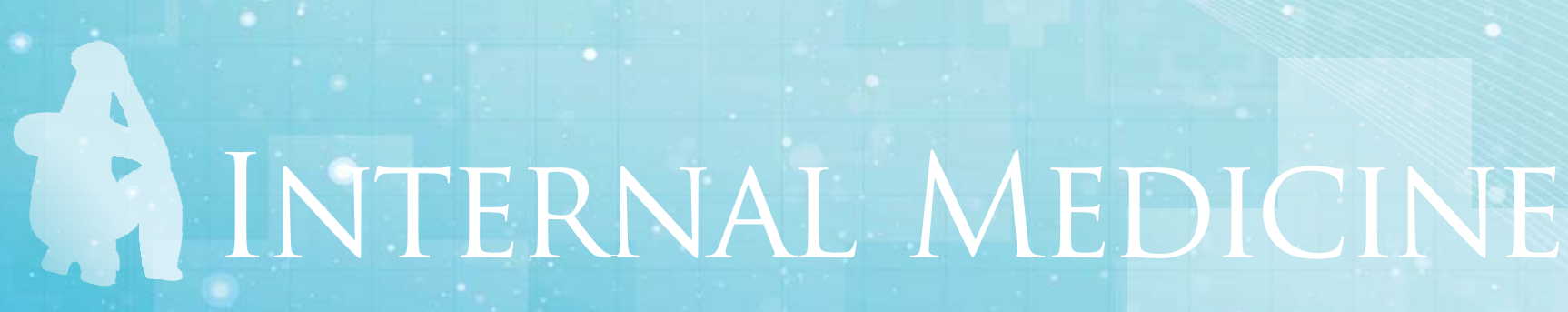
Original Papers

update 2015. Eur HeartJ. 2015 Oct 21;36(40):2696-705. doi: 10.1093/eurheartj/ehv428. Epub 2015 Aug 25. PMID: 26306399.

8. Movsisyan NK, Vinciguerra M, Medina-Inojosa JR, Lopez-Jimenez F. Cardiovascular Diseases in Central and Eastern Europe: A Call for More Surveillance and Evidence-Based Health Promotion. Ann Glob Health. 2020 Feb 26;86(1):21. doi: 10.5334/aogh.2713. PMID: 32166066; PMCID: PMC7059421.

9. LeeJH, Ryu HM, Bae MH, Kwon YS, LeeJH, Park Y, Heo JH, Lee YS, Yang DH, Park HS, Cho Y, Chae SC, Kim YN, Jun JE, Park WH. Prognosis and natural history of drugrelated bradycardia. Korean Circ J. 2009 Sep;39(9):36771. doi: 10.4070/kcj.2009.39.9.367. Epub 2009 Sep 30. PMID: 19949620; PMCID: PMC2771830.

10. Vogler J, Breithardt G, Eckardt L. Bradyarrhythmias and conduction blocks. Rev Esp Cardiol (Engl Ed). 2012 Jul;65(7):656-67. English, Spanish. doi: 10.1016/j. recesp. 2012.01.025. Epub 2012 May 23. PMID: 22627074.

11. Rademaker M. Do women have more adverse drug reactions? Am J Clin Dermatol. 2001;2(6):349-51. doi: 10.2165/00128071-200102060-00001. PMID: 11770389.

12. Deneer VH, van Hemel NM. Is antiarrhythmic treatment in the elderly different? a review of the specific changes. Drugs Aging. 2011 Aug 1;28(8):617-33. doi: 10.2165/11591680-000000000-00000. PMID: 21812498.

13. Brenes-Salazar JA, Alshawabkeh L, Schmader KE, Hanlon JT, Forman DE. Clinical pharmacology relevant to older adults with cardiovascular disease. J Geriatr Cardiol. 2015 May;12(3):192-5. doi: 10.11909/ j.issn.1671-5411.2015.03.018. PMID: 26089839; PMCID: PMC4460158.

14. Marcum ZA, Amuan ME, Hanlon JT, et al. Prevalence of unplanned hospitalizations caused by adverse drug reactions in older veterans. J Am Geriatr Soc. 2012 Jan;60(1):34-41. doi: 10.1111/j.1532-5415.2011. 03772.x. Epub 2011 Dec 8. PMID: 22150441; PMCID: PMC3258324.
15. Mosca L, Barrett-Connor E, Wenger NK. Sex/gender differences in cardiovascular disease prevention: what a difference a decade makes. Circulation. 2011 Nov 8;124(19):2145-54. doi: 10.1161/CIRCULATIONAHA. 110.968792. PMID: 22064958; PMCID: PMC3362050.

16. Hammerman H, Kapeliovich M. Drug-related cardiac iatrogenic illness as the cause for admission to the intensive cardiac care unit. Isr Med Assoc J. 2000 Aug;2(8):577-9. PMID: 10979347.

17. McDonagh TA, Metra M, Adamo M, et al. 2021 ESC Guidelines for the diagnosis and treatment of acute and chronic heart failure. Eur Heart J. 2021 Aug 27:ehab368. doi: 10.1093/eurheartj/ehab368. Epub ahead of print. PMID: 34447992.

18. Yancy CW, Jessup M, Bozkurt B, et al. 2017 ACC/AHA/HFSA Focused Update of the 2013 ACCF/AHA Guideline for the Management of Heart Failure: A Report of the American College of Cardiology/American Heart Association Task Force on Clinical Practice Guidelines and the Heart Failure Society of America. J Card Fail. 2017 Aug;23(8):628-651. doi: 10.1016/j.cardfail. 2017.04.014. Epub 2017 Apr 28. PMID: 28461259.

19. Hindricks G, Potpara T, Dagres N, et al. 2020 ESC Guidelines for the diagnosis and management of atrial fibrillation developed in collaboration with the European Association for Cardio-Thoracic Surgery (EACTS): The Task Force for the diagnosis and management of atrial fibrillation of the European Society of Cardiology (ESC) Developed with the special contribution of the European Heart Rhythm Association (EHRA) of the ESC. Eur Heart). 2021 Feb 1;42(5):373-498. doi: 10.1093/eurheartj/ ehaa612. Erratum in: Eur Heart J. 2021 Feb 1;42(5):507. Erratum in: Eur Heart J. 2021 Feb 1;42(5):546-547. Erratum in: Eur HeartJ. 2021 Sep 14; PMID: 32860505.

20. Khwaja A. KDIGO clinical practice guidelines for acute kidney injury. Nephron Clin Pract. 2012;120(4):c179-84. doi: 10.1159/000339789. Epub 2012 Aug 7. PMID: 22890468.

21. Turakhia MP, Blankestijn PJ, Carrero J, et al. Chronic kidney disease and arrhythmias: conclusions from a Kidney Disease: Improving Global Outcomes (KDIGO) 
Controversies Conference. Eur Heart J. 2018 Jun 21;39(24):2314-2325. doi: 10.1093/eurheartj/ehy060. PMID: 29522134; PMCID: PMC6012907.

22. Wolbrette DL. Risk of proarrhythmia with class III antiarrhythmic agents: sex-based differences and other issues. Am J Cardiol. 2003 Mar 20;91(6A):39D-44D. doi: 10.1016/s0002-9149(02)03378-7. PMID: 12670641.

23. Antonelli D, Atar S, Freedberg NA, Rosenfeld T. Torsade de pointes in patients on chronic amiodarone treatment: contributing factors and drug interactions. Isr Med Assoc J. 2005 Mar;7(3):163-5. PMID: 15792261.

24. EUGenMed Cardiovascular Clinical Study Group, Regitz-Zagrosek V, Oertelt-Prigione S, Prescott E, et al. Gender in cardiovascular diseases: impact on clinical manifestations, management, and outcomes. Eur Heart J. 2016 Jan 1;37(1):24-34. doi: 10.1093/eurheartj /ehv598. Epub 2015 Nov 3. PMID: 26530104.

25. Linde $C$, Bongiorni MG, Birgersdotter-Green $U$, et al. Sex differences in cardiac arrhythmia: a consensus document of the European Heart Rhythm Association, endorsed by the Heart Rhythm Society and Asia Pacific Heart Rhythm Society. Europace. 2018 Oct 1;20(10):1565-1565ao. doi: 10.1093/europace/euy067. PMID: 29961863.

26. Roten L, Rimoldi SF, Schwick N, et al. Gender differences in patients referred for atrial fibrillation management to a tertiary center. Pacing Clin Electrophysiol. 2009 May;32(5):622-6. doi: 10.1111/ j.1540-8159.2009.02335.x. PMID: 19422583.

27. Flather MD, Shibata MC, Coats AJ, et al. Randomized trial to determine the effect of nebivolol on mortality and cardiovascular hospital admission in elderly patients with heart failure (SENIORS). Eur Heart J. 2005
Feb;26(3):215-25. doi: 10.1093/eurheartj/ehi115. Epub 2005Jan 9. PMID: 15642700.

28. Lu HT, Kam J, Nordin RB, Khelae SK, Wang JM, Choy CN, Lee CY. Beta-blocker use and risk of symptomatic bradyarrhythmias: a hospital-based case-control study. J Geriatr Cardiol. 2016 Sep;13(9):749-759. doi: 10.11909/ j.issn.1671-5411.2016.09.009. PMID: 27899939.

29. Ko DT, Hebert PR, Coffey CS, et al. Adverse effects of beta-blocker therapy for patients with heart failure: a quantitative overview of randomized trials. Arch Intern Med. 2004 Jul 12;164(13):1389-94. doi: 10.1001/ archinte.164.13.1389. PMID: 15249347.

30. Bots SH, den Ruijter HM. Recommended Heart Failure Medications and Adverse Drug Reactions in Women. Circulation. 2019 Mar 19;139(12):1469-1471. doi: 10.1161/CIRCULATIONAHA.118.037585. PMID: 30883224.

31. Wehling M. Multimorbidity and polypharmacy: which betablocker to use in relation to the pharmacokinetic profile and interaction potential. Arzneimittelforschung. 2010;60(2):57-63. doi: 10.1055/s-0031-1296249. PMID: 20329652

32. Valodara AM, Sr KJ. Sexual Dimorphism in Drug Metabolism and Pharmacokinetics. Curr Drug Metab. 2019;20(14):1154-1166. doi: 10.2174/1389200 220666191021094906. PMID: 31631817.

33. Rathore SS, Wang Y, Krumholz HM. Sex-based differences in the effect of digoxin for the treatment of heart failure. N Engl J Med. 2002 Oct 31;347(18):140311. doi: 10.1056/NEJMoa021266. PMID: 12409542.

34. Whitley $H$, Lindsey W. Sex-based differences in drug activity. Am Fam Physician. 2009 Dec 1;80(11):1254-8. PMID: 19961138. 